Table 1 Selected CAR-T cell therapies in development

\begin{tabular}{lllllll} 
Project & Company & $\begin{array}{l}\text { Academic } \\
\text { source }\end{array}$ & Indications & $\begin{array}{l}\text { Construct binding } \\
\text { domain/co-stimulatory } \\
\text { domain }\end{array}$ & $\begin{array}{l}\text { Chemo- } \\
\text { conditioning }\end{array}$ & Trial \\
\hline KTE-C19 & Kite & $\begin{array}{l}\text { NCI/Selig } \\
\text { Eshhar }\end{array}$ & $\begin{array}{l}\text { Lymphoma, } \\
\text { adult ALL, } \\
\text { and pediat- } \\
\text { ric ALL }\end{array}$ & $\begin{array}{llll}\text { F-retrovirus transfection } \\
\text { into PBMCs }\end{array}$ & Flu/cy & Zuma-1 \\
& & & & Flu/cy 3 & Zuma 4
\end{tabular}

\begin{tabular}{llllll}
\hline CTL019 Novartis & $\begin{array}{l}\text { University of } \\
\text { Pennsylvania }\end{array}$ & $\begin{array}{l}\text { Pediatric } \\
\text { ALL lym- } \\
\text { phoma }\end{array}$ & $\begin{array}{l}\text { FMC63 (murine)/4-1BB; } \\
\text { lentivirus transfection } \\
\text { into PBMCs }\end{array}$ & Flu/cy & Eliana \\
Juliet
\end{tabular}

\begin{tabular}{|c|c|c|c|c|c|c|}
\hline JCAR015 & Juno & $\begin{array}{l}\text { Memorial } \\
\text { Sloan Kettering } \\
\text { Cancer Center }\end{array}$ & Adult ALL & $\begin{array}{l}\text { SJ25C1 (murine)/CD28; } \\
\gamma \text {-retrovirus transfection } \\
\text { into } \mathrm{CD}^{+} / \mathrm{CD}^{+} \\
\text {co-culture }\end{array}$ & Flu/cy $\rightarrow$ cy & Rocket \\
\hline \multirow[t]{3}{*}{ JCAR017 } & Juno & Seattle & $\mathrm{NHL}$ & FMC63 (murine)/ & Flu/cy & Transcend \\
\hline & & Children's & $\begin{array}{l}\text { Pediatric } \\
\text { ALL }\end{array}$ & $\begin{array}{l}\text { 4-1BB construct with } \\
\text { EGFRt ablation switch }\end{array}$ & \multirow{2}{*}{$\begin{array}{l}\text { Cy or flu/cy } \\
\text { or cy/etop } \\
\text { or flu }\end{array}$} & \multirow[t]{2}{*}{ Plat-02 } \\
\hline & & & & $\begin{array}{l}\text { Lentivirus transfection } \\
\text { into } 1: 1 \text { ratio } C D 4^{+} / C D 8^{+}\end{array}$ & & \\
\hline
\end{tabular}

$\mathrm{NCl}$, National Cancer Institute; Flu, fludarabine; Cy, cyclophosphamide; PBMC, peripheral blood mononuclear cells; FMC63 and SJ25C1, human CD-19 antibody clones; etop, etoposide; NHL, non-Hodgkin's lymphoma.

Source: EP Vantage/EvaluatePharma (London)

and UPenn. These include manufacturing differences-T-cell activation methods, ex vivo culture conditions and the vectors used for the genetic modification-as well as CAR structure such as scFv affinities, and costimulatory domains. "Both can affect the tissue trafficking and cytokine production of CAR-T cells," he says.

Sorting through all the possible factors is challenging. Jacob Plieth, of EP Vantage in London, says, "If you were to design a scientific study to determine what the difference is, you would vary one element and test it, vary another and test it. All we have is CAR-T studies, none of which differ in just one element," he says. Furthermore, neurotoxicity has been observed across multiple traits involving not just CD19 but also B-cell maturation antigen (BCMA), which is being targeted in several multiple myeloma CAR-T programs. What's needed, Milone says, are better animal models for these toxicities. Recent work by Agne Taraseviciute from Seattle Children's Hospital on a nonhuman primate model of cytokine release syndrome with apparent neurotoxicity might be a first step towards developing a useful model.

Plieth, who has been following the field for three years, says that from the start he found that scientifically, the therapy represents "an amazing advance." In addition, in the past few years, much progress has been made in managing side effects, and in taking programs out of single centers into multicenter trials. Further buoying the spirits of followers of CAR-Ts were data presented recently at ASH by several groups on multiple myeloma. Most advanced is Cambridge, Massachusetts-based bluebird bio's program, partnered with Celgene in Summit, New Jersey, that reported a $79 \%$ response rate in nine relapsed refractory multiple myeloma patients treated with its BCMA-targeted CAR-T.

Opinions differ as to whether the FDA was premature in releasing the hold on the Juno trial last July. Jeffrey Weber, an immunotherapist at NYU's Perlmutter Cancer Center feels that the FDA is "really cautious and well aware of the issues with CAR-T cells." On the other hand, says Pleith, "The FDA must realize that in hindsight to allow the resumption of that early hold so quickly was questionable," and he is predicting that they will be extra cautious going forward. "To an extent, people assume you can ditch JCAR015 and the problems with it and everything else will be fine. I'm not sure it's going to be that easy," he says.

It is also possible that patients may have had central nervous system involvement before joining the trials. Weber points out that in the early CAR-T trials, the patients were at a late stage in the disease, and Juno "didn't have a choice. That was your patient population," he says. Weber, who works with checkpoint inhibitors, says, "From everything I've read about CAR-T therapy, it makes dealing with immune adverse events from checkpoint inhibitors look easy," he says.

Laura DeFrancesco Pasadena, California

\section{First mitochondrial DNA transfer go-ahead}

The UK's fertility regulator has approved a three-person IVF procedure that seeks to eliminate mitochondrial diseases transmitted through maternal DNA. The procedure, backed by members of parliament and bioethics councils, was approved by the Human Fertilisation and Embryology Authority on December 15, 2016, for use in specific cases where there is significant risk of developing serious mitochondrial disease. The three-person technique involves a donor oocyte from which the DNA is removed and reconstituted with spindle nuclei transferred from the mother, and sperm. The UK is the first country to legalize the process, though the first child born through spindle nuclear transfer was born in Mexico to a Jordanian couple. Physicians from the New Hope Fertility Center in New York who carried out the procedure reported at the American Society of Reproductive Medicine Scientific Congress \& Expo on October 19 that following an uneventful pregnancy, they delivered a healthy boy, who was doing well three months later. According to a news report that day in Nature, a child conceived using the technique was born in China, and researchers in the Ukraine have said they have impregnated two women using a similar mitochondrial transfer technique called pronuclear transfer, which unlike the transfer of spindle nuclei, requires fertilization of both maternal and donor eggs, followed by the denuclearization of the fertilized donor egg. Both of these techniques, as well as a third mitochondrial replacement therapy, somatic cell nuclear transfer, carry the potential for carry-over of mutant mitochondrial DNA from the mother. Research suggests these mitochondria could outcompete the healthy donor mitochondria, causing disease in the child's tissues. In a November 30 Letter in Nature, researchers from Oregon Health \& Science University in Portland, using spindle nuclear transfer to study neurological diseases, suggest that certain polymorphisms in mitochondrial DNA might amplify the maternal material, a situation that could be minimized by selecting compatible donor mitochondrial DNA.

\section{6 "You can't do it alone. You have to say, 'Hey, we might have been good in the past, but we need insights from others'." Paul Stoffels, CSO at Johnson \& Johnson, refers to the trend in pharma to outsource R\&D. (The Wall Street Journal, 6 December 2016)}

“I really don't think that there's this huge backlog of wonderful therapies piling up behind a big FDA roadblock." Derek Lowe comments in his blog on some provisions in the 21st Century Cures Act that appear to alter the risk-benefit ratio that the FDA should apply to approve new drugs. (In the Pipeline, 5 December 2016) 